\title{
Post-peak supplementation of pasture fed dairy cows with sulla and maize silages
}

\author{
A.V. CHAVES ${ }^{1,2}$, S.L. WOODWARD ${ }^{3}$, G.C. WAGHORN ${ }^{1}$, I.M. BROOKES ${ }^{2}$, \\ C.W. HOLMES ${ }^{2}$ and P.G. LABOYRIE ${ }^{3}$ \\ ${ }^{1}$ AgResearch Grasslands, Private Bag 11008, Palmerston North \\ ${ }^{2}$ Massey University, Private Bag 11222, Palmerston North \\ ${ }^{3}$ Dexcel Ltd, Private Bag 3221, Hamilton \\ alexandre.chaves@agresearch.co.nz
}

\begin{abstract}
A trial was carried out at Dexcel in Hamilton to investigate the effects of silage supplementation of grazing dairy cows post-peak lactation. Forage mixtures used in the four week trial were based on previous trial results and information from in vitro and in sacco incubations. Sulla and maize silages were used to supplement pasture and to meet minimum requirements for protein. Five groups of ten cows were grazed on a restricted daily allowance of $18 \mathrm{~kg}$ dry matter (DM) pasture/cow to simulate a summer pasture deficit, and four groups received sulla silage (S) or maize silage (M) alone or in mixtures of $25 \mathrm{M}: 15 \mathrm{~S}$ or $15 \mathrm{M}: 25 \mathrm{~S}$ to make up $40 \%$ of total DM intake. A sixth group was given an unrestricted (38 kg DM/cow/day) pasture allowance. The pasture was of high nutritive value and not typical of usual summer conditions, which limited the effects of supplementation in the trial. The restricted pasture allowance resulted in a low level of substitution (0.29) when the silages were fed and substantially increased feed intakes. Although differences in cow responses to the silage mixtures were minor, liveweight and milk production were improved relative to restricted pasture allowance but not for cows given $38 \mathrm{~kg}$ pasture DM/ day. The low level of substitution demonstrated the impact of the restricted pasture allowance on cow performance. In sacco data show highest DM degradation rate $\left(\mathrm{k}, \mathrm{h}^{-1}\right)$ when cows were fed pasture with sulla silage $(0.08)$; diets with a high proportion of maize silage were degraded slowly $(\mathrm{P}<0.01)$. Supplementation with sulla may increase digestion rate and rumen clearance and reduce the effect of fibre in ryegrass diets.
\end{abstract}

Keywords: dairy cows, maize, pasture, silage, sulla

\section{Introduction}

The productivity and nutritive value of perennial ryegrass dominant pasture is a constraint to future increases in productivity in New Zealand dairy systems (Clark et al. 2001). The quality and quantity of nutrients available to grazing animals varies widely because of changes due to season, maturity and management practices. Ryegrass pastures can have low dry matter in spring and high fibre concentrations in summer which may restrict feed intake, so that animal nutrient requirements are often not met (Waghorn 2002).
This experiment was designed to improve the nutrition of cows given restricted pasture allowance in summer. Supplementation can increase and sustain milk production through to the end of lactation but responses will depend on pasture quality and the type of supplement offered (Bryant \& Trigg 1982; Holmes 1987; Thompson et al. 1998; Woodward et al. 2002).

The variation in forage quality and the difficulty in quantifying intake are major challenges for farmers (Holmes et al. 2002). Ideally, carbohydrates and protein should be supplied in a ratio that optimizes microbial protein synthesis and flow of microbial nitrogen $(\mathrm{N})$ to the small intestine, and also meets the nutrient requirements of the cow.

Previous research with maize silage (M) and sulla silage (S) emphasised the importance of meeting the cow's protein requirements (Woodward et al. 2002) especially since the very low protein concentration in $\mathrm{M}$ makes it unsuitable as a supplement for low quality summer pasture. Sulla is not widely used but it is a high yielding legume containing condensed tannins (CT) and a high concentration of readily fermented carbohydrates, which offer good potential for high quality silage production (Niezen et al. 1998).

The objectives of this trial were to determine the benefits of feeding sulla silage, alone and in combination with maize silage, to cows given access to a restricted allowance of grass dominant pasture in summer.

\section{Material and methods}

Sixty Friesian cows [ 15 primiparous and 45 multiparous; $483 \mathrm{~kg}$ liveweight; $14.3 \mathrm{~kg}$ milk/day; 156 days in milk] were allocated to six treatments and balanced for milksolids yield and liveweight. The overall design comprised a uniformity (covariance) period of one week, when all cows were grazed on pasture enabling their subsequent allocation to six groups fed the experimental diets for three weeks. Two cows with permanent rumen fistulae were included in each treatment except those given restricted pasture. They enabled in sacco incubations of the dietary mixtures.

The six treatments were full pasture (FP, $38 \mathrm{~kg} \mathrm{DM}$ allowance/cow/day); restricted pasture (RP, $18 \mathrm{~kg} \mathrm{DM}$ allowance /cow/day); PMS: restricted pasture $(60 \%)+$ maize silage (25\%) + sulla silage (15\%); PSM: restricted 
pasture $(60 \%)+$ sulla silage $(25 \%)+$ maize silage $(15 \%)$; PS: restricted pasture $(60 \%)+$ sulla silage $(40 \%)$; and PM: restricted pasture $(60 \%)+$ maize silage $(40 \%)$.

\section{Feeding}

Pasture and milk yield measurements were made on Tuesday, Wednesday and Thursday of each week. On these three days each group of 10 cows was split into two groups of 5 cows (with the same cows in each group each week) in order to replicate the treatments. On the remaining four days of each week the replicate groups were combined into treatment groups (six herds of 10 cows).

The full allowance ( $38 \mathrm{~kg}$ DM/cow/day) of pasture was intended to provide unrestricted feed, while the other restricted pasture allowance of $18 \mathrm{~kg} \mathrm{DM} /$ cow/day was intended to mimic summer conditions with feed shortages. Cows in each treatment group were given a new break of pasture once daily using electric fences, and water was always available. Daily pasture allowances for each treatment group were estimated by visual assessment of pre-grazing herbage mass and allocation of the appropriate area to be grazed. Silage was fed to the four groups of cows in portable feed troughs (one trough per 5 cows), after the cows returned to the paddock following the morning milking. Silage was weighed before feeding and a sub-sample quickly dried in a microwave oven so that cows were offered $6 \mathrm{~kg}$ silage DM/cow/day. Troughs were removed from paddocks when cows were at grazing height) and sub-samples of the silages were taken on three measurement days to measure nutrient composition of the feed offered by NIRS (Corson et al. 1999). Sub-samples of silage refusals were collected on the same three days and bulked to provide one sample per week for NIRS analysis.

Liveweight (LW) was measured before milking on three mornings per week before and during the trial. Milk yield was measured for each cow on three days per week, and sub-samples taken for analysis of the concentration of fat, protein, lactose, and of somatic cell count.

Digestion kinetics were determined for each diet by mixing constituents, freezing and mincing to resemble chewed forage (Barrell et al. 2000). In sacco bags were removed at $0,2,6,9,12,24,48$ and 72 hours, dried and analysed to determined rates of disappearance during digestion.

\section{Results and discussion}

The FP treatment produced the highest intakes and milk yield, with an extra $4.2 \mathrm{~kg}$ milk from an extra $5.3 \mathrm{~kg}$ DM. The RP treatment group lost $12 \mathrm{~kg}$ live weight during the 3 week period. The supplemented groups produced 0.5 to $1.1 \mathrm{~kg}$ milk more than the RP group (Table 1).

Pasture intake by the four supplemented groups decreased about $1.6 \mathrm{~kg} \mathrm{DM} /$ day through substitution (Table 1), with about $5.5 \mathrm{~kg}$ silage equivalent to a

Table 1 Daily milk yield, liveweight and dry matter intakes (DMI) over the three week measurement period.

\begin{tabular}{|c|c|c|c|c|c|c|c|}
\hline & $\mathrm{RP}$ & $\mathrm{FP}$ & PMS & PSM & PS & $\mathrm{PM}$ & $\mathrm{LSD}^{1}$ \\
\hline $\begin{array}{l}\text { Milk, kg/day } \\
\text { Change in liveweight (kg) } \\
\text { Pasture DMI (kg/day) } \\
\text { Silage DMI (kg/day) } \\
\text { Total DMI (kg/day) } \\
\text { Pasture utilization }{ }^{2}(\%) \\
\text { Substitution rate }\end{array}$ & $\begin{array}{l}13.2 \\
-12.4 \\
10.4 \\
10.4 \\
59\end{array}$ & $\begin{array}{l}17.2 \\
-3.8 \\
15.7 \\
15.7 \\
42\end{array}$ & $\begin{array}{l}14.3 \\
+1.0 \\
8.8 \\
5.8 \\
14.6 \\
50 \\
0.28\end{array}$ & $\begin{array}{l}13.7 \\
-4.5 \\
9.0 \\
5.4 \\
14.4 \\
51 \\
0.27\end{array}$ & $\begin{array}{l}13.7 \\
-0.8 \\
8.7 \\
5.2 \\
13.9 \\
49 \\
0.32\end{array}$ & $\begin{array}{l}13.7 \\
-1.4 \\
8.8 \\
5.5 \\
14.3 \\
49 \\
0.29\end{array}$ & $\begin{array}{l}1.0 \\
3.4 \\
1.6 \\
0.3 \\
2.3 \\
3.8\end{array}$ \\
\hline
\end{tabular}

${ }^{1}$ Least significant difference $(P<0.05)$

${ }^{2} \mathrm{~kg}$ DM pasture eaten/kg DM pasture offered.

afternoon milking and refusals weighed. The dry matter contents of the silages offered and refused were determined by drying at $100^{\circ} \mathrm{C}$ for 24 hours.

\section{Measurements}

Pasture intakes by each treatment group were determined by using a rising plate meter to estimate pre and postgrazing herbage mass ( 50 measures per area grazed for 24 hours). This was done three times per week for each treatment group. Weekly pasture cuts (pre and postgrazing on representative pasture) were used to calibrate the rising plate meter.

Pre-grazing pasture samples (several cuts to estimated substitution rate of about 1.6/5.5 $=0.29$. All supplements had a similar substitution rate $(0.27-0.32)$ which showed a substantial increase in feed intake was possible by providing silages with a pasture allowance of $18 \mathrm{~kg} \mathrm{DM} /$ cow day, even though it was of unusually high quality (Table 2). This level of substitution is low compared to other data when grazing cows were offered silages (Stockdale 1996) or grains (Dalley et al. 2001).

Milk production responses to $6 \mathrm{~kg}$ silage $\mathrm{DM}(+0.5$ to $1.1 \mathrm{~kg}$ milk) were lower than from an allowance of an additional $20 \mathrm{~kg}$ pasture DM (FP treatment; $+4.2 \mathrm{~kg}$ milk), but the silages also reduced live weight loss considerably (from $-12 \mathrm{~kg}$ to $+1 \mathrm{~kg}$ ). The pasture 
Table 2 Composition of diets feed to cows.

\begin{tabular}{lllllllll}
\hline Dietary composition (\%) & RP & FP & PMS & PSM & PS & PM & LSD $^{1}$ & SE \\
\hline Dry matter & 15.9 & 17.4 & 26.5 & 24.6 & 25.2 & 25.4 & 4.85 & 1.3 \\
Crude protein & 21.5 & 21.7 & 16.5 & 18.0 & 18.8 & 15.4 & 3.95 & 0.6 \\
Soluble carbohydrates & 9.1 & 9.2 & 16.1 & 12.7 & 6.9 & 21.9 & 0.74 & 0.4 \\
Fibre (NDF ${ }^{2}$ ) & 44.1 & 43.9 & 45.1 & 45.8 & 47.9 & 43.0 & n.S. & 0.4 \\
Fibre (ADF & 24.9 & 24.4 & 27.3 & 28.3 & 31.6 & 24.7 & 2.96 & 0.5 \\
Fat & 3.9 & 4.0 & 3.9 & 4.1 & 4.3 & 3.5 & 0.29 & 0.04 \\
ME (M)/kg DM) & 10.6 & 10.7 & 10.5 & 10.6 & 10.6 & 10.6 & n.S. & 0.1 \\
\hline
\end{tabular}

${ }^{1}$ Least significant difference $(P<0.05)$.

${ }^{2} \mathrm{NDF}=$ cellulose, hemicellulose and lignin

${ }^{3} \mathrm{ADF}=$ cellulose and lignin.

n.s. = no significant difference.

$\mathrm{SE}=$ standard error.

available in January 2002 was of excellent quality, whilst the sulla had been harvested about six weeks late and was quite stalky.

Pasture DM on offer averaged $3141 \mathrm{~kg} / \mathrm{ha}$ for all treatments, with post grazing residuals of $1525 \mathrm{~kg} / \mathrm{ha}$ for cows given a restricted allowance and $1814 \mathrm{~kg} \mathrm{DM} / \mathrm{ha}$ for cows given a full allowance. Pasture DM utilization was $59 \%$ for RP and $50 \%$ across the four silage supplemented treatments (Table 1). Cows given full pasture allowance ate $42 \%$ of that on offer.

The supplementary feeds were intended to meet cow requirements for crude protein $(\mathrm{CP})$, through addition of urea if necessary, and the values in Table 2 show this was achieved with the exception of the PM diet which was slightly less than a desirable 16-17\% CP in DM for cows in mid lactation (NRC 2001). There were no differences $(\mathrm{P}<0.05)$ between diets in concentration of fibre (NDF) and estimated ME (Table 2) but soluble carbohydrates were highest when maize silages were used and lowest with sulla. Provision of silages increased the dietary DM concentration $(\mathrm{P}<0.001)$.

Given that all silage treatments provided a similar level of nutrition, indicated by LW change and milk yield, and that $86-96 \%$ of silage offered was eaten, the responses to FP were probably due to increased feed intake. The cows offered $18 \mathrm{~kg}$ pasture DM/day (RP treatment) ate $10.4 \mathrm{~kg}$. DMI is closely related to pasture allowance (Holmes et al. 2002) and $18 \mathrm{~kg} \mathrm{DM} / \mathrm{cow} /$ day resulted in $58 \%$ pasture utilization compared to $42 \%$ when $38 \mathrm{~kg}$ $\mathrm{DM} /$ cow/day was offered. The restrictions applied to cows given silage supplements mimicked pasture deficits faced by farmers when pasture is in short supply and silages are given to increase feed availability. However, a higher allowance may have enabled a better expression of silage nutritive value because feed restrictions would be less severe.

Digestion kinetics demonstrated significant differences between diets, with maize silage reducing rates of DM disappearance relative to pasture. Sulla fed with pasture had the most rapid DM digestion (Table 3). In contrast to
Table 3 Rates of DM and crude protein disappearance, $k\left(h^{-1}\right)$ from fresh minced forages incubated in nylon bags in the rumen of fistulated cows fed full pasture and four silages supplements.

\begin{tabular}{lcccc}
\hline & \multicolumn{2}{c}{-- DM ---} & \multicolumn{2}{c}{ Crude } \\
Diet & $\mathrm{k}$ & $\mathrm{SE}$ & $\mathrm{k}$ & $\mathrm{SE}$ \\
\hline FP & 0.07 & 0.002 & 0.12 & 0.008 \\
PS & 0.08 & 0.003 & 0.09 & 0.009 \\
P SM & 0.07 & 0.003 & 0.08 & 0.009 \\
PMS & 0.05 & 0.003 & 0.07 & 0.008 \\
PM & 0.05 & 0.003 & 0.13 & 0.008 \\
\hline P & 0.01 & & 0.02 & \\
\hline
\end{tabular}

$\mathrm{SE}=$ standard error

$\mathrm{P}=$ significance level.

DM disappearance, the rate of protein degradation was reduced when sulla was included in the diet, possibly in response to the protection conferred by condensed tannins in sulla. Reduced protein degradation rate is likely to increase protein availability for the absorption and increase nutritive value for cows.

Although there were no differences in responses between the individual silage supplement treatments, the PMS resulted in the highest milk yield without liveweight loss (Table 1). This diet also met cows requirements for $\mathrm{CP}$ and provided $16.1 \%$ soluble carbohydrates, suggesting a relatively high nutritive value despite its high NDF concentration (45\%). The PSM diet, with the higher protein concentration may have been more appropriate as a supplement for low protein pasture expected under normal, dry, summer conditions.

\section{Conclusion}

The dairy farmer faces the task of maintaining a desired level of production often when the quality of pasture is less than optimal and as pasture is likely to provide the cheapest source of nutrients it is important to maximise feed intake at minimal cost. Silage supplements can be used to fill summer feed deficits when pasture quality declines due to maturation of ryegrass. To achieve positive 
responses from supplements, pasture should have lower quality (nutritive value) than supplements and the supplements must be chosen to complement the pasture on offer. The differences between digestion kinetics of maize and sulla silage supplements demonstrate the importance of selecting an appropriate supplement to complement the pasture on offer.

\section{REFERENCES}

Barrell, L.G.; Burke, J.L.; Waghorn, G.C.; Attwood, G.T.; Brookes, I.M. 2000. Preparation of fresh forages for incubation and prediction of nutritive value. Proceedings of New Zealand Society of Animal Production 60: 5-8.

Bryant, A.M.; Trigg, T.E. 1982.The nutrition of the grazing dairy cow in early lactation. pp. 185-207. In: Dairy production from pasture. Eds. Macmillan, K.L.; Taufa, V.K. New Zealand Society of Animal Production, Hamilton, New Zealand.

Clark, D.A.; Matthew, C.; Crush, J.R. 2001. More feed for New Zealand dairy systems. Proceedings of the New Zealand Grassland Association 63: 283-288.

Corson, D.C.; Waghorn, G.C.; Ulyatt, M.J.; Lee, J. 1999. NIRS: Forage analysis and livestock feeding. Proceedings of the New Zealand Grassland Association 61: 127-132.

Dalley, D.E.; Roche, J.R.; Grainger, C. 2001. Effect of grain or buffer supplementation on milk solids yield and rumen fermentation patterns of cows grazing highly digestible herbage in spring. Proceedings of the New Zealand Society of Animal Production 61: 224-228.
Holmes, C.W.; Brookes, I.M.; Garrick, D.J.; MacKenzie, D.D.S.; Parkinson, T.J.; Wilson, G.F. 2002. Milk production from pasture. Massey University, Palmerston North, New Zealand.

Holmes, C.W. 1987. Pastures for dairy cows. pp. 133143. In: Livestock feeding on pasture. Ed. Nicol, A.M. New Zealand Society of Animal Production. Occasional publication No.10, Hamilton, New Zealand.

Niezen, J.H.; Waghorn, G.C.; Lyons, T.B.; Corson, D.C. 1998. The potential benefits of ensiling the forage legume sulla compared with pasture. Proceedings of the New Zealand Grassland Association 60: 105-109.

National Research Council. 2001. Nutrient requirements of dairy cattle ( $7^{\text {th }}$ Rev. Ed.). National academy press, Washington, D.C. 381 pp.

Stockdale, C.R. 1996. Substitution and production responses when lactating dairy cows graze a white clover pasture supplemented with maize silage. Australian Journal of Experimental Agriculture 36: 771-776.

Thompson, N.A.; Davis, K.L.; McGrath, J.M.; Hainsworth, R.J.; Clough, J.C. 1998. Impact of feeding maize silage on dairy production. Proceedings of the New Zealand Grassland Association 60:51-55.

Waghorn, G. 2002. Can forages match concentrate diets for dairy production? Proceedings of the New Zealand Society of Animal Production 62: 261-266.

Woodward, S.L.; Chaves, A.V.; Grayling, L.; Waghorn, G.C. 2002. Supplementing pasture fed dairy cows with pasture silage, maize silage, Lotus silage or sulla silage in summer - does it increase production? Proceedings of the New Zealand Grassland Association 64: 85-89. 